\title{
AVAILABILITY OF URINARY ALBUMIN MEASUREMENT IN SOUTHERN BRAZILIAN LABORATORIES
}

\author{
Ariana Aguiar Soares ${ }^{1}$, Amanda Veiga Cheuiche ${ }^{1}$, Alexandre Sauer \\ da Silva ${ }^{1}$, Larissa Petermann Jung ${ }^{1}$, Joíza Lins Camargo ${ }^{1,2}$, \\ Sandra Pinho Silveiro ${ }^{1,3}$
}

\section{ABSTRACT}

Introduction: Diabetic kidney disease (DKD) is the leading worldwide cause of endstage renal disease. The current recommendation is to screen for DKD by evaluating estimated glomerular filtration rate (eGFR) and measuring urinary albumin (UA) levels in a spot sample. The aim of this study was to evaluate the availability of UA measurement in Southern Brazilian laboratories.

Methods: A cross-sectional study was conducted to assess the routine use of UA in all laboratories registered in the State Pharmacy Council of Rio Grande do Sul, the southernmost state of Brazil. Data was collected by mail, e-mail, telephone, or personal interview. A sample size of at least 384 laboratories was necessary to achieve 5\% precision at a $95 \%$ confidence level based on a fixed proportion of 0.5 .

Results: Eight hundred and eighty laboratories currently registered in the state were invited to participate in the study; $548(62 \%)$ answered the technical specification questionnaire. Only 306 (55\%) of the 548 surveyed laboratories performed UA measurements. The laboratories were also required to provide the number of UA measurements performed per day, which ranged from less than one per week to 65 per day.

Conclusion: The availability of UA measurements is undesirably low in Southern Brazil. This demonstrates the urgent need to increase the availability of this important test. It also reveals the gap between the current guidelines and the awareness about them among health care professionals.

Keywords: Diabetes kidney disease; diabetes mellitus; urinary albumin measurement; albuminuria; diabetic nephropathy

Diabetic kidney disease (DKD) is a serious microvascular complication of diabetes mellitus (DM), and the leading worldwide cause of end-stage renal disease ${ }^{1,2}$. The early detection of DKD allows for the use of strategies to halt its development or at least delay the progression of the disease ${ }^{3}$.

The current recommendation is to screen for DKD by measuring albumin levels in a spot urine collection, which accurately replaces 24 -h collections, and by evaluating serum creatinine to estimate the glomerular filtration rate (eGFR). International and national guidelines advocate the performance of these tests in patients with type 1 diabetes after 5 years of the disease, and in all patients with type 2 DM starting at diagnosis ${ }^{4-6}$.

Unfortunately, albumin measurement procedures are not readily available in all clinical laboratories, especially in low-income countries. The aim of this study was to evaluate the availability of urinary albumin (UA) measurement in Southern Brazilian laboratories.

Clin Biomed Res. 2015;35(1):55-58 1 Programa de Pós-Graduação em Ciências Médicas: Endocrinologia, Universidade Federal do Rio Grande do Sul (UFRGS). Porto Alegre, RS, Brazil.

2 Serviço de Patologia Clínica, Hospital de Clínicas de Porto Alegre (HCPA). Porto Alegre, RS, Brazil.

3 Serviço de Endocrinologia, Hospital de Clínicas de Porto Alegre (HCPA). Porto Alegre, RS, Brazil.

Corresponding author: Sandra Pinho Silveiro E-mail: silveirosandra@gmail.com Hospital de Clínicas de Porto Alegre Serviço de Endocrinologia Rua Ramiro Barcelos, 2350, 90035-903, Porto Alegre, RS, Brazil. 


\section{METHODS}

A survey was conducted to assess the routine use of renal function tests (UA and eGFR) in all laboratories registered in the State Pharmacy Council of Rio Grande do Sul, the southernmost state of Brazil. The state area is divided geographically into north and south regions ${ }^{7,8}$. Our results regarding the prevalence and reporting of eGFR testing have been previously published ${ }^{9}$.

This cross-sectional study started in July 2010 and ended in July 2012. The investigation was approved by the Research Ethics Committee of our institution (protocol no. 10-0129), and each laboratory agreed to participate in the survey. The variable of interest was assessed by a technical specification survey including the following questions: 1) Is urinary albumin measured in your laboratory? 2) How many albumin measurements are performed daily? Data was collected by mail, e-mail, telephone, or personal interview.

A sample size of at least 384 laboratories was necessary to achieve $5 \%$ precision at a $95 \%$ confidence level based on a fixed proportion of $0.5^{10}$. Statistical analyses were performed using the Predictive Analytics Software (PASW) package, version 20.0 (Statistical Package for the Social Sciences-Professional Statistics TM, Chicago, IL, USA).

\section{RESULTS}

Of the 880 laboratories registered in the state and invited to participate in the survey, $548(62 \%)$ answered the technical specification questionnaire (figure 1). Of these, $403 / 648(62 \%)$ were located in the northern region and 145/232 (64\%) were located in the southern region of the state, thus ensuring the geographic representativeness of the data collected (figure 2).

Of the 548 respondents, 306 (55\%) reported to perform UA measurement at their laboratories. Of the 242 that did not measure UA, 56 sent the samples to be analyzed by an external laboratory. Thirty-four $(6.9 \%)$ laboratories informed that they were only able to measure total protein concentration in urine.

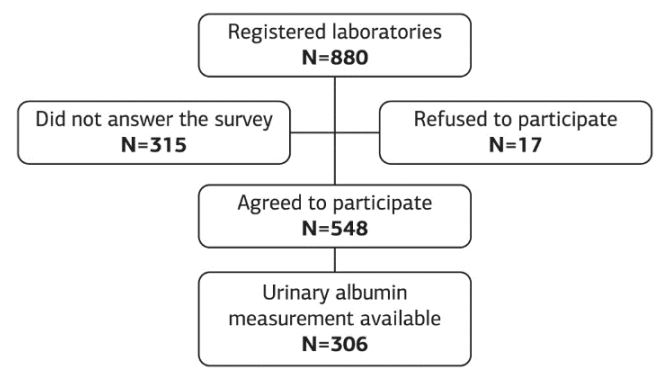

Figure 1: Flowchart of the participating laboratories.
The laboratories were also asked about the number of albumin measurement procedures performed per day, which ranged from less than one per week to 65 per day.

\section{DISCUSSION}

Our study revealed that only half of the Southern Brazilian laboratories included in this study perform UA measurements. This alarming low rate is in contrast with the efforts of national and international DM care guidelines, which recommend the use of annual UA measurements to identify the presence of $D K D^{4-6}$. Poor accessibility to kidney function assessment has also been reported in other regions in the world. Only $33 \%$ of patients in North Africa ${ }^{11}$ and $30 \%$ of individuals with type $2 \mathrm{DM}$ in some regions of Finland perform urinary albumin tests on a yearly basis ${ }^{12}$. A recent systematic review evaluating the standards for DM care in Central and South America found that the prevalence of annual albuminuria screenings among patients with DM ranged from 1-80\%, which reveals the presence of significant heterogeneity in patient care, with important barriers to healthcare ${ }^{13}$. Fortunately, some countries have much higher albuminuria screening rates, such as Israel, where approximately $72.6 \%$ of patients undergo annual screening tests ${ }^{11}$. In the United States, the first national initiative to establish a set of measures to assess patients with DM has been developed recently and it includes $\mathrm{HbA} 1 \mathrm{c}$, low-density lipoprotein, and blood pressure measurements, in addition to eye and renal examinations ${ }^{14}$. Therefore, a similar national task force in this regard is clearly necessary in our country.

Albuminuria is a very simple and low-cost procedure, hardly costing more than 2-3 dollars. It is easily



Figure 2: Map of Rio Grande do Sul with laboratories in the North and South regions. 
adaptable to automatization, which only requires the use of routine equipment, readily available in most ordinary laboratories. Furthermore, the validity of the use of a spot urine albumin sample to detect DKD is worldwide recognized, replacing the cumbersome 24-h urine collection to screen for elevated albumin levels, additionally simplifying the procedure ${ }^{5}$. At most, a second collection may be necessary to confirm the diagnosis due to the high coefficient of variation of this measurement ${ }^{15}$. Therefore, there appears to be no justifiable reason for laboratories not to perform UA measurement procedures. In addition, governmental policies should implement task forces to ensure that this test is accessible to every patient. We found that some laboratories did not perform UA because the test is seldom requested (data not shown). In this regard, we identify a serious gap between the guidelines and physicians' awareness about them, thus showing the need for further education and training of health care staff.

Albuminuria was first suggested as a marker of kidney disease in 1969, when Harry Keen and colleagues demonstrated a slight increase in UA excretion - microalbuminuria - during a glucose test in patients with $\mathrm{DM}$, using a sensitive radioimmunoassay method $^{16}$. Since then, UA assessments have been extensively used as a tool to predict advanced kidney disease, cardiovascular events, and increased mortality ${ }^{17}$. However, the reliability of UA as a diagnostic tool for DKD has been questioned by some authors, since only one-third of the patients with increased UA excretion progress to more advanced stages of the disease ${ }^{3}$. Furthermore, approximately $25 \%$ of patients with DM have normal UA, and the diagnosis of DKD is based on reduced GFR levels only ${ }^{18}$. Nevertheless, even though other new kidney disease biomarkers have been investigated, none of them demonstrated better diagnostic performance than albuminuria in screening for DKD ${ }^{19}$. Recent investigations with proteomics approach suggest that this technique, in a near future, might be able to identify diabetes renal involvement earlier ${ }^{20}$. As for now, UA has been the most extensively studied DKD marker, and is arguably the best method to screen for the condition.
The latest DKD guidelines recommend replacing the terms micro- and macroalbuminuria with the term "increased albuminuria", since it appears to convey in a more accurate manner the idea of a continuum of risk. This idea is corroborated by our own previous findings, as well as by those of other studies, which have demonstrated that even "highnormal" albuminuria may be predictive of advanced kidney disease and mortality ${ }^{1,21}$.

Surprisingly, it was only recently that a candidate liquid chromatography-mass spectrometry (LC-MS/ MS) was developed as a reference measurement procedure to assess $\mathrm{UA}^{22}$. Another reference measurement procedure has been developed in the Mayo Clinic Renal Function Laboratory, using trypsin digestion of whole urine followed by LC-MS/MS ${ }^{23}$. This initiative will allow for the standardization and harmonization of UA measurements.

A limitation of our survey is that it applies only to the southernmost region of Brazil. The wealthy Southeast region (where São Paulo and Rio de Janeiro are located) could perhaps return better results. On the other hand, in the Northern region of Brazil, the poorest region of the country, an even worse scenario could be probably found.

In conclusion, in our region, the availability of urinary albumin measurements is undesirably low, indicating an urgent need to increase the availability of this simple, albeit important, procedure.

\section{Acknowledgements}

The authors would like to thank the Research Incentive Fund (FIPE) of the Hospital de Clínicas de Porto Alegre and the Graduate Program in Medical Sciences: Endocrinology (PPG Endocrinology) for its financial support. AVC and AAS are supported by the National Council for Scientific and Technological Development (CNPq) grants and LPJ is supported by the Research Support Foundation of the State of Rio Grande do Sul (FAPERGS).

\section{Conflicts of Interest}

The authors declare no conflicts of interest.

\section{REFERENCES}

1. Murussi M, Campagnolo N, Beck MO, Gross JL, Silveiro SP. Highnormal levels of albuminuria predict the development of micro- and macroalbuminuria and increased mortality in Brazilian Type 2 diabetic patients: an 8-year follow-up study. Diabet Med. 2007;24(10):1136-42. http://dx.doi.org/10.1111/j.14645491.2007.02209.x. PMid:17561963

2. Gross JL, de Azevedo MJ, Silveiro SP, Canani LH, Caramori ML, Zelmanovitz T. Diabetic nephropathy: diagnosis, prevention, and treatment. Diabetes Care. 2005;28(1):164-76. http:// dx.doi.org/10.2337/diacare.28.1.164 PMid:15616252

3. Fineberg D, Jandeleit-Dahm KA, Cooper ME. Diabetic nephropathy: diagnosis and treatment. Nat Rev Endocrinol. 2013;9(12):713-23. http:// dx.doi.org/10.1038/nrendo.2013.184. 
PMid:24100266

4. Kidney Disease. KDIGO 2012 Clinical Practice Guideline for the Evaluation and Management of Chronic Kidney Disease. Kidney Int Suppl. 2013;3(1):1-150.

5. American Diabetes Association (ADA). Standards of medical care in diabetes - 2015. Diabetes Care. 2015;38(Suppl 1):S14-80.

6. International Diabetes Federation (IDF). Global guideline type 2 diabetes. IDF; 2012. [cited 2014 Oct 5]. Available from: www.idf.org.

7. Instituto Brasileiro de Geografia e Estatística (IBGE). 2014. [cited 2014 Dec 1]. Available from: http://www. ibge.gov.br/home/.

8. Brasil. Ministério da Integração Nacional. 2014. [cited 2014 Dec 1]. Available from: http:// www.mi.gov.br/programas/ programasregionaismetadesul/ abrangencia.asp.

9. Soares AA, Cheuiche AV, Silva AS, Rostirolla MJ, Jung LP, Horta BL, et al. Low rates of automatic reporting of estimated glomerular filtration rate in Southern Brazilian laboratories. Clin Biochem. 2013;46(16-17):170912. http://dx.doi.org/10.1016/j. clinbiochem.2013.08.025. PMid:24028898

10. Lwanga SK, Leweshow S. Determinación del tamaño de las muestras en los estúdios sanitários - Manual práctico. Ginebra: Organización Mundial de la Salud; 1991.

11. Zabetian A, Keli HM, EchouffoTcheugui JB, Narayan KM, Ali MK. Diabetes in the Middle East and North Africa. Diabetes Res Clin Pract. 2013;101(2):106-22. http://dx.doi. org/10.1016/j.diabres.2013.03.010.
PMid:23642969

12. Honkasalo MT, Linna M, Sane T, Honkasalo A, Elonheimo O. A comparative study of two various models of organising diabetes followup in public primary health care - the model influences the use of services, their quality and costs. BMC Health Serv Res. 2014;14(1):26. http:// dx.doi.org/10.1186/1472-6963-14-26. PMid:24444378

13. Mudaliar U, Kim WC, Kirk K, Rouse C, Narayan KM, Ali M. Are recommended standards for diabetes care met in Central and South America? A systematic review. Diabetes Res Clin Pract. 2013;100(3):30629. http://dx.doi.org/10.1016/j. diabres.2013.01.010. PMid:23375230

14. Aron DC. Quality indicators and performance measures in diabetes care. Curr Diab Rep. 2014;14(3):472. http://dx.doi.org/10.1007/s11892-0130472-y. PMid:24496919

15. Miller WG, Bruns DE, Hortin GL, Sandberg S, Aakre KM, McQueen $\mathrm{MJ}$, et al. Current issues in measurement and reporting of urinary albumin excretion. Clin Chem. 2009;55(1):24-38. http://dx.doi. org/10.1373/clinchem.2008.106567. PMid:19028824

16. Keen H, Chlouverakis C, Fuller J, Jarrett RJ. The concomitants of raised blood sugar: studies in newly-detected hyperglycaemics: II. Urinary albumin excretion, blood pressure and their relation to blood sugar levels. Int $J$ Epidemiol. 2014;43(1):11-5. http:// dx.doi.org/10.1093/ije/dyt257 . PMid:24381008

17. Parving HH. Commentary: microalbuminuria: past, present and glorious future. Int $J$ Epidemiol. 2014;43(1):21-2. http:// dx.doi.org/10.1093/ije/dyt255. PMid:24381009
18. Maclsaac RJ, Tsalamandris C, Panagiotopoulos S, Smith TJ, McNeil $\mathrm{KJ}$, Jerums G. Nonalbuminuric renal insufficiency in type 2 diabetes. Diabetes Care. 2004;27(1):195200. http://dx.doi.org/10.2337/ diacare.27.1.195. PMid:14693989

19. Maclsaac RJ, Ekinci El, Jerums G. Markers of and risk factors for the development and progression of diabetic kidney disease. Am J Kidney Dis. 2014;63(Suppl 2):S39-62. http:// dx.doi.org/10.1053/j.ajkd.2013.10.048. PMid:24461729

20. Zürbig $P$, Jerums $G$, Hovind $P$, Macisaac RJ, Mischak H, Nielsen SE, et al. Urinary proteomics for early diagnosis in diabetic nephropathy. Diabetes. 2012;61(12):3304-13. http://dx.doi.org/10.2337/db12-0348. PMid:22872235

21. Rachmani R, Levi Z, Lidar M, Slavachevski I, Half-Onn E, Ravid M. Considerations about the threshold value of microalbuminuria in patients with diabetes mellitus: lessons from an 8-year follow-up study of 599 patients. Diabetes Res Clin Pract. 2000;49(2-3):187-94. http://dx.doi. org/10.1016/S0168-8227(00)00155-8. PMid:10963831

22. Lieske JC, Bondar O, Miller WG, Bachmann LM, Narva AS, Itoh Y, et al. A reference system for urinary albumin: current status. Clin Chem Lab Med. 2013;51(5):981-9. http:// dx.doi.org/10.1515/cclm-2012-0768. PMid:23241608

23. Seegmiller JC, Barnidge DR, Burns BE, Larson TS, Lieske JC, Kumar R. Quantification of urinary albumin by using protein cleavage and LC-MS/MS. Clin Chem. 2009;55(6):1100-7. http://dx.doi. org/10.1373/clinchem.2008.115543. PMid:19325011 